\title{
VZTAH ATOPICKÉHO EKZÉMU A POZORNOSTI
}

\author{
Alena Hricová, Stanislav Ondrášek, Matyáš Hric
}

\begin{abstract}
Abstrakt
Cílem přehledové studie je popsat vztah dvou proměnných - atopického ekzému a pozornosti. Nejprve je důležité vymezit dva související pojmy, které je důležité nezaměňovat, a to ADHD a ADD. Obě tyto poruchy pozornosti jsou dědičné neurovývojové poruchy. ADD se vyznačuje ztrátou soustředění, roztržitostí a emoční přecitlivělostí. ADHD je porucha pozornosti s hyperaktivitou. Vyznačuje se nepozornosti, hyperaktivitou a impulzivitou. Na základě výsledků dostupných studií, které se tímto vztahem zaobírají, je čtenáři představena daná tématika a shrnuty dosavadní poznatky. Pro přehledovou studii bylo pracováno se zdroji z dostupných vědeckých databází: PubMed, PsycInfo, Scopus a Web of Science. Pro vyhledávání byla zadána klíčová slova: atopic eczema, $\mathrm{ADHD}, \mathrm{ADD}$, attention, relationship. Dalším zvoleným kritériem pro vyhledávání bylo sledované období, které jsme stanovili bez určení, důvodem pro toto rozhodnutí bylo, že se jedná o specifickou problematiku. Studie byly vybrány na základě relevantnosti ke stanovenému cíli. Celkem se jednalo o 10 analyzovaných studií. Výsledky analyzovaných studií ukazují, že u osob s diagnostikovaným atopickým ekzémem existuje riziko poruchy pozornosti. Zároveň však nebyl prokázán př́mý kauzální vztah mezi těmito proměnnými, který by v případě prokázání mohl vést ke stanovení preventivních, ale i léčebných plánů.
\end{abstract}

Klíčová slova: atopický ekzém, pozornost, ADHD, ADD

\section{Impact of atopic eczema on attention}

\section{Abstract}

PROBLEM: Atopic eczema is linked with several other psychosomatic diseases and disorders like sleeping disorders or low quality, chronic itching, etc. First, it is important to define two related terms that are important not to confuse, namely ADHD and ADD. Both of these attention disorders are inherited neurodevelopmental disorders. ADD is characterized by loss of concentration, distraction, and emotional hypersensitivity. ADHD is an attention deficit hyperactivity disorder. It is characterized by inattention, hyperactivity, and impulsivity. The survey study aims at describing the relation of two variables - atopic eczema and attention. Based on the results of the available studies dealing with the said relation, the topic will be presented to the reader and the existing pieces of knowledge will be summarized. METHODS: The study worked with sources from available scientific databases: PubMed, PsycInfo, Scopus and Web of Science. The following key words were entered for search: atopic eczema, ADHD, ADD, attention, relation. Another criterion selected for search was the period of observation, which we set without determination; that decision was based on the fact that the topic in question is specific. The studies were selected based on their relevance for the goal set. 10 studies were analyzed in total.

RESULTS: The analysis results show that studies dealing with the issue of the effect of atopic eczema can be divided into two groups. The first group consists of studies which state, based on research, that persons with diagnosed atopic eczema are endangered by attention disorders. While comparing them with healthy population, i.e., with persons without atopic eczema, it 
was found that persons with atopic eczema have higher proportional chance of attention disorders, and other health problems linked with the said disease, like low quality of sleep, anxieties, depressions or behaviour disorders were registered as well. The studies under analysis also mention a risk period that may be essential for the development of attention disorder. The other group consists of studies which did not demonstrate a direct causal relation between attention eczema and attention disorders, which, if demonstrated, could lead to setting of preventive and therapeutic plans. The results of some of these studies show the coexistence of atopic eczema and ADHD, but the authors state that both disorders may not have causal relation and that they may be influenced by other factors; they recommend other studies which could clarify the prevalence of ADHD in persons with atopic eczema. DISCUSSION AND CONCLUSION: In conclusion, it can be stated that there is a higher risk of attention disorder, ADHD, in individuals with atopic eczema. However, as studies show, a causal relation between the two variables in question has not been found yet. The results have also shown that this issue is still little explored, in spite of the fact that a number of studies had a large research set. Therefore, further extensive interdisciplinary studies are needed, in order to prove or disprove their mutual causal relation. In case of proving the causal relation, it is further recommended to proceed to determine preventive and therapeutic strategies for attention disorders caused by atopic eczema, in order to positively influence the resulting quality of life of the individuals with the said disorder type.

Keywords: atopic eczema, attention, $A D H D, A D D$

Došlo do redakce: 19.1 .2021

Schváleno k publikaci: 2. 8. 2021 


\section{Úvod}

Poruchy pozornosti mají výrazný vliv na život jedince, a to jak v běžných společenských interakcích, tak také v rámci vzdělávání, zaměstnání apod. Podobný vliv má i atopický ekzém, který se zároveň vyznačuje i viditelnými kožními symptomy. Cílem této přehledové studie je proto popsat vztah atopického ekzému a pozornosti. Pro analýzu byly zvoleny studie zabývající se poruchou pozornosti a jejími prŕćčnami. Studie byly čerpány s databází odborných publikací: PubMed, PsycInfo, Scopus a Web of Science. Pro vyhledávání byla zadána klíčová slova: atopický ekzém, ADHD, ADD, pozornost, vztah, resp. atopic eczema, ADHD, ADD, attention, relationship. Dalším zvoleným kritériem pro vyhledávání bylo sledované období, které jsme stanovili bez určení, důvodem pro toto rozhodnutí bylo, že se jedná o specifickou problematiku. Studie byly vybrány na základě relevantnosti ke stanovenému cíli. Celkově do přehledové studie bylo zařazeno a analyzováno 10 studií. Bylo pracováno s plnými verzemi analyzovaných studií, a to na základě př́stupu univerzity ke zmíněným databázím.

\section{Terminologie}

Atopický ekzém (AE) je častým kožním onemocněním. V průmyslově vyspělých zemích atopický ekzém podle statistiky postihne zhruba $20 \%$ dětí a $10 \%$ dospělých (Tsakok et al., 2019). Je spojován s chronickým svěděním, alergickým onemocněním a poruchami spánku. V mezinárodní klasifikaci nemocí je značena pod kódem L20, jakožto Atopická dermatitida a L20.9 Atopická dermatitida NS (WHO, Mezinárodní statistická klasifikace nemocí a přidružených zdravotních problémů, 2020). Jedná se o zánětlivé onemocnění kůže, které je charakteristické opakujícími se svědivými exantémovými lézemi (Weidinger et al., 2018). Podle Grönhagena et al. (2015) je vyrážka doprovázena otokem, mokváním a svěděním, nejčastěji se vyskytuje na obličeji a pokožce hlavy či končetin a trupu. Meng (2016) dále zmiňuje tzv. začarovaný kruh, který je spojen se snahou pacienta ulevit si od svědění škrabáním, které sice chvilkově pomůže, ale ve své podstatě stav ještě zhoršuje, nebot' stimulací nervových vláken $\mathrm{v}$ důsledku narušené bariéry vede k uvolňování zánětlivých a rezidentních buněk. Noda (2015) a Vachiramon (2012) se shodují, že se klinické projevy ovšem mohou individuálně lišit.

Jednotlivé klinické projevy slouží k hodnocení a měření závažnosti za pomoci tzv. indexu závažnosti (ve zkratce EASI) a indexu objektivního bodování (ve zkratce SCORAD) (Schmitt, 2014).

Důležité je ovšem též zmínit, že AE nezasahuje pouze tělesnou schránku jedince, ale může mít vliv také na jeho mentální schopnosti (Yaghmaie et al., 2013 a Silverberg, 2017).

ADD (zkratka anglického Attention Deficit Disorder), neboli porucha pozornosti je dědičná neurovývojová porucha, kterou je specifická nemožnost udržení pozornosti pro určitou činnost (Hallowell a Rateay, 2010). Mezi nejčastější př́iznaky se dle Pelletiera (2014) řadí rychlá ztráta soustř̌edění při vnitřních i vnějších podnětech, roztržitost, tzv. denní snění, potíže s uspořádáním věcí či časté zapomínání, avšak nesmí docházet k opomíjení emoční přecitlivělosti či potížemi v sociálních vztazích (tj. obtížné navazování přátelství a jeho udržení). Pokyn NICE č. 87 (National Institute for Health and Care Excellence, 2018) konstatuje, že je důležité nezaměňovat ADD za ADHD. ADHD (zkratka anglického attention deficit hyperactivity disorder), neboli porucha pozornosti s hyperaktivitou, je geneticky podmíněná neurovývojová porucha. 
Mezi základní příznaky patří nepozornost, hyperaktivita a impulzivita, které se pak později v různých životních obdobích mění. Je to porucha, která se často objevuje v dětství a dále přetrvává do dospělosti. Narušeny jsou především exekutivní funkce i kvalita života jedince, porucha má genetický základ a je celoživotní (Theiner, 2012).

\section{Vztah atopického ekzému a pozornosti}

Výsledky dostupných studií shrnuje tabulka 1 níže. Autoři Strom a kol. (2016) ve své studii tvrdí, že je obecně známo, že atopický ekzém v dětství souvisí se zvýšeným rizikem poruchy pozornosti ADHD a nižší kvalitou spánku. Dále ve studii dochází ke čtyřem výsledkům vlastního zkoumání, kterými jsou:

1) Atopický ekzém a poruchy spánku synergicky a nezávisle na sobě přispívají ke zhoršování průběhu ADHD.

2) Atopický ekzém samotný je rovněž spojen se zvýšeným rizikem poruchy pozornosti jak u dětí, tak u dospělých.

3) Obezita, bolesti hlavy a anémie dále zvyšují riziko ADHD u dětí s atopickým ekzémem.

4) Astma, bolesti hlavy a nespavost zvyšují riziko ADHD u dospělých pacientů atopického ekzému. Výsledky byly zjištěny na základě analýzy 354416 dětí ve věku od dvou do 17 let a 34613 dospělých ve věku 18+. Výsledky potvrzují zvýšené riziko poruch pozornosti u dětí i dospělých trpících na atopický ekzém, nicméně vzájemný vztah těchto dvou proměnných zůstává stále nedostatečně prozkoumán.

Ve výzkumném článku autorů J. Schmitta a kol. (2009) bylo odhaleno 5,2 \% prevalence ADHD mezi dětmi trpícími atopickým ekzémem a 3,4 \% mezi dětmi zdravými. Autoři však konstatují, že tato zjištění naznačují nezávislou asociaci mezi atopickým ekzémem a ADHD a je zapotřebí dalších výzkumů, zaměřených na kauzální vztah těchto dvou proměnných a určení směru pozorované asociace. Dále dle nich zůstává nejasné, zda je zpozorované zvýšené procento ADHD u dětí s atopickým ekzémem způsobeno tímto onemocněním, nebo zda za to mohou sekundární jevy, jako je svědění, poruchy spánku či psychosociální problémy. Rovněž zmiňují potenciál špatné klasifikace symptomů AE a ADHD u zkoumaných pacienti̊.

O rok později publikuje J. Schmitt společně s A. Buske-Kirschbaumem a V. Roessnerem (2010) rešerši, v níž potvrzuje, že celkem šest různých studií uvádělo pozitivní souvislost mezi atopickým ekzémem a ADHD; jedna z nich navíc navrhuje tuto souvislost poupravit o faktor kvality spánku. Autoři dále zmiňují některé stejné nedostatky daných studií, a to konkrétně nemožnost potvrdit příčinnou souvislost těchto dvou jevů, nebot' jsou studie často průřezové či bez př́slušných měření expozice. Ve studiích dále chybí dostatečná definice atopického ekzému i ADHD. Dalším omezením zkoumaných studií je dle autorů nezahrnutí matoucího faktoru a komorbidit jako jsou bakteriální a virové infekce, ale i astma a alergie spojené s jídlem (Paller et al, 2018; Silverberg, 2017; Silverberg, 2019; Simpson, 2012). Je tak nutné upozornit na př́ípadný kontext těchto onemocnění, ačkoli se jim citované studie nevěnují. Autoři rovněž navrhují nutnost dalších vysoce kvalitních interdisciplinárních studií k lepšímu pochopení mechanismů a vzájemných vztahů mezi atopickým ekzémem a ADHD, které by vedly k následnému stanovení preventivních a léčebných strategií. V roce 2017 Jurjen van der Schans a kol. vytvořili systematický přehled mezi průřezovými studiemi a kvantitativními metaanalýzami, za účelem aktualizování rešerše od Schmitta a kol. (2010). 
Studie odhalily vyšší riziko ADHD u dětí s atopickou chorobou. V analýze bylo zjištěno 1,5násobné zvýšené riziko ADHD, které odpovídá výsledkům J. Schmitta, A. BuskeKirschbauma a V. Roessnera (2010). V této analýze byla však navíc také nalezena nezávislá souvislost s výskytem ADHD mezi astmatem a rýmou.

V roce 2018 přichází J. Schmitt a kol. (2018) s další studií, která se zabývá tímto tématem a nabízí výsledky porovnání čtyř zkoumaných skupin; a to: děti s atopickým ekzémem (pouze), děti s ADHD (pouze), děti s atopickým ekzémem a ADHD, a děti, kteří netrpí ani atopickým ekzémem, ani ADHD. Výsledky této studie ukazují, že všechny tři skupiny dětí (AE, ADHD a AE+ADHD) vykazovaly signifikantně zvýšené problémy s chováním a sníženou kvalitu života. Dále bylo v této studii potvrzeno, že děti trpící na atopický ekzém, kterým nebylo prímo diagnostikováno ADHD, i tak vykazovaly vyšší hladiny příznaků ADHD než děti, které tímto ekzémem netrpí. V roce 2019 A. Buske-Kirschbaum a kol. (2018) uvádějí další studii, kdy si za cíl určují, zda je změněna osa HPA u dětí s AE, ADHD a komorbidní AE + ADHD ve srovnání s HC. Výsledky této studie ukazují významně změněnou aktivitu osy HPA u dětí s ADHD a AE+ADHD.

Studie autorů Yaghmaie a kol. (2013) byla provedena na základě dat od 91642 oslovených dětí, kompletní data poskytlo $51 \%$ z nich. Ve studii bylo zjišsěno, že u dětí s atopickým ekzémem se vyskytují více než u běžné populace poruchy pozornosti ADHD, úzkosti, deprese, poruchy chování či autismus. Autoři dále dodávají, že atopický ekzém u dětí je spojen s ADHD i z důvodu nedostatku spánku. Tento nedostatek pak roste s vážností ekzému.

Studie autorů Tsai a kol. (2013) potvrzuje, že děti s atopickým ekzémem mají vyšší náchylnost k ADHD a zároveň potvrzuje, že existuje korelace mezi atopickým ekzémem a poruchami pozornosti ADHD. Rovněž zmiňují, že pokud by atopický ekzém byl přícinou poruch pozornosti, potom by jeho léčba mohla znamenat i prevenci ADHD. Autoři studie rovněž doporučují další provedení patofyziologických výzkumů a longitudinálních studií zaměřených na sledování dětí s atopickými stavy a neurobehaviorálním problémem, aby tak byly přidány další podstatné důkazy na podporu těchto korelací.

Chih-Ying Lee a kol. (2016) ve své studii potvrzují, že přítomnost alergických onemocnění, mezi něž patří i atopický ekzém, souvisí s rizikem rozvoje hyperaktivity a poruchami pozornosti (ADHD). Současné studie podle autorů však stále nejsou dostatečně průkazné. Ve své studii se pak hlouběji soustředí na vztah následujících dvou jevů: atopický ekzém v batolecím věku a poruchy pozornosti později v dětství. Zkoumaným vzorkem byla všechna batolata a děti od jednoho měsíce do tři let narozeny v letech 1998-2008 (n=18 473), jež trpěly atopickým ekzémem. U všech zmíněných dětí byl později proveden výzkum na míru prítomnosti ADHD či autismu. Za pomocí multivariační Coxovy regresní analýzy bylo zjištěno, že přítomnost atopického ekzému u batolat významně zvýšila riziko rozvoje ADHD nebo autismu u dětí starších tří let. Autoři lékařům, kteří s batolaty pracují, doporučují, aby si rozšířili znalosti o toto riziko pozdějšího výskytu ADHD u dětí s atopickým ekzémem.

Německá, na dotaznících založená studie autorů J. Genuneita a kol. (2014), v níž bylo zkoumáno celkem 770 dětí do věku 11 let, rovněž potvrzuje zvýšení riziko ADHD u dětí trpících atopickým ekzémem, ale pouze v krátkém období po diagnostice atopického ekzému. V porovnání s touto studií však Riis a kol. (2016) potvrzují zvýšené riziko i v dalších obdobích. 
Studie autorů Riise a kol. (2016) zahrnuje všechny děti do 15 let, narozené mezi lety 1995 a 2010, kterým byl diagnostikován atopický ekzém. Z výsledků studie vyšlo najevo, že u dětí s atopickým ekzémem převládá vyšší procento dětí trpící poruchami pozornosti než u běžné populace. Nebyl však potvrzen prričinný vztah těchto dvou jevů. Autoři dále navrhují, aby lékaři u dětí s atopickým ekzémem rovněž sledovali jejich duševní zdraví.

Tabulka 1: Výsledky dostupných studií vztahu atopického ekzému a pozornosti

\begin{tabular}{|c|c|c|c|c|}
\hline Autor & Rok & & Metodika & Výsledky \\
\hline & & \multicolumn{2}{|c|}{ Atopický ekzém a pozornost } & \\
\hline & & \multicolumn{2}{|c|}{ Atopický ekzém a ADHD } & \\
\hline $\begin{array}{l}\text { Schmitt } \\
\text { a kol. }\end{array}$ & 2010 & $\begin{array}{l}\text { Jednorázový } \\
\text { výzkum }\end{array}$ & rešerše & $\begin{array}{l}\text { Celkem šest různých studií } \\
\text { uvádělo pozitivní souvislost mezi } \\
\text { atopickým ekzémem a ADHD. } \\
\text { Autoři však zmiňují nemožnost } \\
\text { potvrdit příčinnou souvislost } \\
\text { těchto dvou jevů, nebot' jsou studie } \\
\text { často průřezové či bez příslušných } \\
\text { měření expozice. Ve studiích dále } \\
\text { chybí dostatečná definice } \\
\text { atopického ekzému i ADHD. }\end{array}$ \\
\hline $\begin{array}{l}\text { Yaghmaie } \\
\text { a kol. }\end{array}$ & 2013 & $\begin{array}{l}\text { Jednorázový } \\
\text { výzkum }\end{array}$ & $\begin{array}{l}\mathrm{n}=91642 \text { dětí, data } \\
\text { získaná dotazníkovou } \\
\text { metodou. Pro analýzu } \\
\text { použití logistických } \\
\text { regresních modelů a } \\
\text { softwaru SPSS a SAS. } \\
\text { Pro srovnání mezi } \\
\text { skupinami byly pro } \\
\text { kontinuální proménné } \\
\text { použity nezávislé t } \\
\text { testy a pro nominální } \\
\text { proměnné byly použity } \\
\text { chí kvadráty. Byly } \\
\text { rovněž provedeny } \\
\text { vícerozměrné Coxovy } \\
\text { regresní analýzy. }\end{array}$ & $\begin{array}{l}\text { Ve studii bylo zjištěno, že u dětí } \\
\text { s atopickým ekzémem se vyskytují } \\
\text { více než u běžné populace poruchy } \\
\text { pozornosti ADHD, úzkosti, } \\
\text { deprese, poruchy chování či } \\
\text { autismus. Autoři dále dodávají, že } \\
\text { atopický ekzém u dětí je spojen } \\
\text { s ADHD i z důvodu nedostatku } \\
\text { spánku. Tento nedostatek pak roste } \\
\text { s závažností ekzému. } \\
\text { Atopický ekzém a ADHD bylo } \\
\text { zjištěno kladnou odpovědí na } \\
\text { otázku, zda jim v posledních } 12 \\
\text { měsících lékař sdělil tuto } \\
\text { diagnózu. }\end{array}$ \\
\hline $\begin{array}{l}\text { Genuneit } \\
\text { a kol. }\end{array}$ & 2014 & $\begin{array}{l}\text { Longitudinální } \\
\text { výzkum }\end{array}$ & $\begin{array}{l}\mathrm{n}=770, \text { dotazníková } \\
\text { metoda }\end{array}$ & $\begin{array}{l}\text { Zvýšené riziko ADHD u dětí } \\
\text { trpících atopickým ekzémem, ale } \\
\text { pouze v krátkém období po } \\
\text { diagnostice atopického ekzému. } \\
\text { Informace o atopickém ekzému a } \\
\text { ADHD zjištěny od rodičů a } \\
\text { ošetřujících lékařů. }\end{array}$ \\
\hline
\end{tabular}




\begin{tabular}{|c|c|c|c|c|}
\hline Strom a kol. & 2016 & $\begin{array}{l}\text { Transverzální } \\
\text { výzkum }\end{array}$ & $\begin{array}{l}\text { analýza } 354416 \text { dětí } \\
\text { ve věku od dvou do } 17 \\
\text { let a } 34613 \text { dospělých } \\
\text { ve věku } 18+\text {. }\end{array}$ & $\begin{array}{l}\text { 1) Atopický ekzém a poruchy } \\
\text { spánku synergicky a nezávisle na } \\
\text { sobě přispívají ke zvýšenému } \\
\text { riziku ADHD. } \\
\text { 2) Atopický ekzém samotný je } \\
\text { rovněž spojen se zvýšeným } \\
\text { rizikem poruchy pozornosti jak } \\
\text { u dětí, tak u dospělých. } \\
\text { Informace o atopickém ekzému a } \\
\text { ADHD zjištěny z dotazníků. }\end{array}$ \\
\hline $\begin{array}{l}\text { Chih-Ying } \\
\text { Lee a kol. }\end{array}$ & 2016 & $\begin{array}{l}\text { Jednorázový } \\
\text { výzkum }\end{array}$ & $\begin{array}{l}\mathrm{n}=18473 \text { batolat, jež } \\
\text { trpěly atopickým } \\
\text { ekzémem }\end{array}$ & $\begin{array}{l}\text { Přítomnost atopického ekzému } \\
\text { u batolat významně zvyšuje riziko } \\
\text { rozvoje ADHD nebo autismu } \\
\text { u dětí starších tří let. } \\
\text { Informace o atopickém ekzému a } \\
\text { ADHD zjištěny z výzkumné } \\
\text { databáze NHIRD. }\end{array}$ \\
\hline $\begin{array}{l}\text { Schmitt } \\
\text { a kol. }\end{array}$ & 2017 & $\begin{array}{l}\text { Transverzální } \\
\text { výzkum }\end{array}$ & $\begin{array}{l}\text { porovnání čtyř } \\
\text { zkoumaných skupin: } \\
\text { děti s atopickým } \\
\text { ekzémem (pouze), děti } \\
\text { s ADHD (pouze), děti } \\
\text { s atopickým ekzémem } \\
\text { a ADHD a děti, kteří } \\
\text { netrpí ani atopickým } \\
\text { ekzémem, ani ADHD. }\end{array}$ & $\begin{array}{l}\text { Všechny tři skupiny dětí (AE, } \\
\text { ADHD a AE+ADHD) vykazovaly } \\
\text { signifikantně zvýšené problémy } \\
\text { s chováním a sníženou kvalitu } \\
\text { života. Děti s AE vyšší příznaky } \\
\text { ADHD (byt' u nich nebylo přímo } \\
\text { diagnostikováno). } \\
\text { Informace o atopickém ekzému a } \\
\text { ADHD zjištěny z anamnézy. }\end{array}$ \\
\hline $\begin{array}{l}\text { van der } \\
\text { Schans a kol. }\end{array}$ & 2017 & $\begin{array}{l}\text { Jednorázový } \\
\text { výzkum }\end{array}$ & rešerše & $\begin{array}{l}\text { Tři hlavní atopické nemoci, včetně } \\
\text { astmatu, ekzému a alergické rýmy, } \\
\text { jsou v dětství nezávisle spojeny } \\
\text { s ADHD, jednotlivci mají } \\
\text { v průměru o } 30 \text { až } 50 \text { \% větší šanci } \\
\text { na rozvoj ADHD. }\end{array}$ \\
\hline
\end{tabular}

\begin{tabular}{|c|c|c|c|c|}
\hline & \multicolumn{2}{|c|}{$\begin{array}{l}\text { Atopický ekzém a ADHD - navzájem } \\
\text { nekauzální vztah }\end{array}$} & \\
\hline $\begin{array}{l}\text { Absolon } \\
\text { a kol. }\end{array}$ & 1997 & $\begin{array}{l}\text { Jednorázový } \\
\text { výzkum }\end{array}$ & $\begin{array}{l}\text { Vzorek: děti ve věku } \\
\text { od } 5 \text { do } 15 \text { let. Data } \\
\text { sbírána pomocí } \\
\text { dotazníku. Děti a } \\
\text { jejich psychické } \\
\text { problémy včetně } \\
\text { problémů s pozorností } \\
\text { byly vyhodnoceny } \\
\text { dětským psychiatrem } \\
\text { pomocí stupnice } \\
\text { Rutter A2. }\end{array}$ & $\begin{array}{l}\text { U dětí s atopickým ekzémem } \\
\text { nebyla zaznamenána vyšší hladina } \\
\text { symptomů poruchy pozornosti než } \\
\text { u běžné dětské populace. } \\
\text { Informace o atopickém ekzému a } \\
\text { ADHD zjištěny pomocí dotazníku. }\end{array}$ \\
\hline
\end{tabular}




\begin{tabular}{|c|c|c|c|c|}
\hline $\begin{array}{l}\text { Schmitt } \\
\text { a kol. }\end{array}$ & 2009 & $\begin{array}{l}\text { Jednorázový } \\
\text { výzkum }\end{array}$ & $\begin{array}{l}\text { Korelační studie, } \\
\mathrm{n}=600 \text { 000, děti (6-12 } \\
\text { let) a dospívající } \\
\text { (13-17 let), } \\
\text { ke zkoumání byly } \\
\text { použity dva logistické } \\
\text { regresní modely. } \\
\text { V primární analýze byl } \\
\text { AE modelován jako } \\
\text { binární proměnná } \\
\text { (přítomnost vs. } \\
\text { neprrítomnost). } \\
\text { Sekundární průzkumná } \\
\text { analýza byla } \\
\text { prováděna na základě } \\
\text { četnosti konzultací } \\
\text { v důsledku AE. }\end{array}$ & $\begin{array}{l}\text { Bylo odhaleno } 5,2 \% \text { prevalence } \\
\text { ADHD mezi dětmi trpícími } \\
\text { atopickým ekzémem a } 3,4 \% \text { mezi } \\
\text { dětmi zdravými. Autoři však } \\
\text { komentují, že tato zjištění } \\
\text { naznačují nezávislou asociaci mezi } \\
\text { atopickým ekzémem a ADHD a je } \\
\text { zapotřebí dalších výzkumů. } \\
\text { Informace o atopickém ekzému a } \\
\text { ADHD zjištěny z databáze. }\end{array}$ \\
\hline $\begin{array}{l}\text { Buske- } \\
\text { Kirschbaum } \\
\text { a kol. }\end{array}$ & 2013 & $\begin{array}{l}\text { Jednorázový } \\
\text { výzkum }\end{array}$ & rešerše & $\begin{array}{l}\text { Zjištění koexistence AE a ADHD, } \\
\text { přičemž obě poruchy nemusí } \\
\text { souviset příčinně. }\end{array}$ \\
\hline Riis a kol. & 2016 & $\begin{array}{l}\text { Longitudinální } \\
\text { studie }\end{array}$ & $\begin{array}{l}\text { Analýza dat dánské } \\
\text { národní zdravotní } \\
\text { služby, analyzovány } \\
\text { děti do } 15 \text { let, } \\
\text { narozené mezi lety } \\
1995 \text { a } 2010, \text { kterým } \\
\text { byl diagnostikován } \\
\text { atopický ekzém, } \\
\text { zkoumáno, zda byly } \\
\text { předepsány léky na } \\
\text { ADHD. Porovnáváno } \\
\text { s dětmi netrpícími na } \\
\text { AE. }\end{array}$ & $\begin{array}{l}\text { U dětí s atopickým ekzémem } \\
\text { převládá vyšši procento dětí } \\
\text { trpících poruchami pozornosti než } \\
\text { u běžné populace. Nebyl však } \\
\text { potvrzen př́činný vztah těchto } \\
\text { dvou jevo̊. } \\
\text { Informace o ADHD zjištěny } \\
\text { z databáze DPCR. }\end{array}$ \\
\hline $\begin{array}{l}\text { Buske- } \\
\text { Kirschbaum } \\
\text { a kol. }\end{array}$ & 2018 & $\begin{array}{l}\text { Jednorázový } \\
\text { výzkum }\end{array}$ & $\begin{array}{l}\mathrm{n}=42, \text { děti ve věku } \\
6-12 \text { let s AE } \\
\mathrm{n}=34, \text { děti s ADHD } \\
\mathrm{n}=31, \mathrm{~s} \mathrm{AE}+\mathrm{ADHD} \\
\mathrm{n}=47, \mathrm{~s} \mathrm{HC}\end{array}$ & $\begin{array}{l}\text { Analýza dat neukázala žádné } \\
\text { rozdíly mezi věkem dětí, avšak } \\
\text { u chlapců }(p=0,026) \text { byla zjištěna } \\
\text { větší prevalence AE a ADHD, } \\
\text { skupiny dětí s AE vykazovaly } \\
\text { vyšší hodnoty v impulzivitě a } \\
\text { nepozornosti oproti skupině dětí } \\
\text { s HC, významně změněnou } \\
\text { aktivitu osy HPA mají děti } \\
\text { s ADHD a AE-ADHD, nenašly se } \\
\text { však důkazy pro pozměněnou } \\
\text { funkci osy HPA u dětí s AE. } \\
\text { Informace o atopickém ekzému a } \\
\text { ADHD zjištěny na základě } \\
\text { diagnostiky. }\end{array}$ \\
\hline
\end{tabular}




\section{Závěr}

Závěrem lze konstatovat, že u jedinců s atopickým ekzémem existuje vyšší riziko poruchy pozornosti ADHD. Jak však studie dokazují, nebyl prozatím nalezen prŕíčinný vztah mezi těmito dvěma proměnnými. Výsledky taktéž ukázaly, že tato problematika je stále málo prozkoumaná, a to i přesto, že se v řadě prrípadů jednalo o studie s rozsáhlým výzkumným souborem. $\mathrm{V}$ dané problematice nebyl nalezen výzkum zaměřený na to, jak se mění vztah mezi atopickým ekzémem a poruchami pozornosti v čase, tedy vývojový pohled, i tento jev by byl vhodný do budoucna sledovat pro lepší zachycení vztahu mezi poruchami pozornosti a atopickým ekzémem. Je tak zapotřebí dalších rozsáhlých interdisciplinárních studií, které se zaměří na potvrzení či vyvrácení jejich vzájemného kauzálního vztahu. V př́ípadě potvrzení kauzálního vztahu je dále doporučeno následné stanovení preventivních a léčebných strategií poruch pozornosti způsobených atopickým ekzémem, které mohou výrazně pozitivně ovlivnit výslednou kvalitu života osoby s tímto typem onemocnění.

\section{Literatura}

Absolon, C. M., Cottrell, D., Eldridge, S. M., \& Glover, M. T. (1997). Psychological disturbance in atopic eczema: The extent of the problem in school-aged children. British Journal of Dermatology, 137(2), 241-245. https://doi.org/10.1046/j.13652133.1997.18121896.x

National Institute for Health and Care Excellence. (2018, update September 2019). Attention deficit hyperactivity disorder: Diagnosis and management. NICE Guideline, No. 87. https://www.ncbi.nlm.nih.gov/books/NBK493361/

Buske-Kirschbaum, A., Schmitt, J., Plessow, F., Romanos, M., Weidinger, S., \& Roessner, V. (2013). Psychoendocrine and psychoneuroimmunological mechanisms in the comorbidity of atopic eczema and attention deficit/hyperactivity disorder. Psychoneuroendocrinology, 38(1), 12-23. https://doi,org/10.1016/j.psyneuen.2012.09.017

Buske-Kirschbaum, A., Trikojat, K., Tesch, F., Schmitt, J, Roessner, V., Luksch, H., RösenWolff, A., \& Plessow, F. (2018). Altered hypothalamus-pituitary-adrenal axis function: A relevant factor in the comorbidity of atopic eczema and attention deficit/hyperactivity disorder? Psychoneuroendocrinology, 105, 178-186. https://doi.org/10.1016/j.psyneuen.2018.12.005

Genuneit, J., Braig, S., Brandt, S., Wabitsch, M., Florath, I., Brenner, H., \& Rothenbacher, D. (2014). Infant atopic eczema and subsequent attention-deficit/hyperactivity disorder - A prospective birth cohort study. Pediatric Allergy and Immunology, 25(1), 51-56. https://doi.org/10.1111/pai.12152

Grönhagen, C., Lidén, C., Wahlgren, C., Ballardini, N., Bergström, A., Kull, I., \& Meding, B. (2015). Hand eczema and atopic dermatitis in adolescents: A prospective cohort study from the BAMSE project. British Journal of Dermatology, 173(5), 1175-1182. https://doi.org/10.1111/bjd.14019

Hallowell, E. M., \& Ratey, J. J. (2010). Answers to distraction. Anchor Books.

Lee, C., Chen, M., Jeng, M., Hsu, J., Tsai, S., Bai, Y., Hung, G., Yen, H., Chen, T., \& Su, T. (2016). Longitudinal association between early atopic dermatitis and subsequent attention-deficit or autistic disorder. Medicine, 95(39). https://doi.org/10.1097/md.0000000000005005

Meng, J., \& Steinhoff, M. (2016). Molecular mechanisms of pruritus. Current Research in Translational Medicine, 64(4), 203-206. https://doi.org/10.1016/j.retram.2016.08.006 
MKN-10: Mezinárodní statistická klasifikace nemocí a přidružených zdravotních problémů: Desátá revize: Obsahová aktualizace k 1. 1. 2018. (2020). Ústav zdravotnických informací a statistiky ČR.

Noda, S., Suárez-Fariñas, M., Ungar, B., Kim, S. J., Strong, C. D., Xu, H., \& GuttmanYassky, E. (2015). The Asian atopic dermatitis phenotype combines features of atopic dermatitis and psoriasis with increased TH17 polarization. Journal of Allergy and Clinical Immunology, 136(5), 1254-1264. https://doi:10.1016/j.jaci.2015.08.015

Paller, A., Jaworski, J. C., Simpson, E. L., Boguniewicz, M., Russell, J. J., Block, J. K., Tofte, S., Dunn, J. D., Feldman, S. R., Clark, A. R., Schwartz, G., \& Eichenfield, L. F. (2018). Major comorbidities of atopic dermatitis: Beyond allergic disorders. American Journal of Clinical Dermatology, 19(6), 821-838. https://doi.org/10.1007/s40257-018-0383-4

Pelletier, E. (2014). Porucha pozornosti bez hyperaktivity: Pomoc rodičům a učitelưm. Portál.

Riis, J. L., Vestergaard, C., Deleuran, M. S., \& Olsen, M. (2016). Childhood atopic dermatitis and risk of attention deficit/hyperactivity disorder: A cohort study. Journal of Allergy and Clinical Immunology, 138(2), 608-610. https://doi.org/10.1016/j.jaci.2016.01.027

Schmitt, J. (2009). Atopic eczema and attention-deficit/hyperactivity disorder in a populationbased sample of children and adolescents. Jama, 301(7), 724. https://doi.org/10.1001/jama.2009.136

Schmitt, J., Buske-Kirschbaum, A., \& Roessner, V. (2010). Is atopic disease a risk factor for attention-deficit/hyperactivity disorder? A systematic review. Allergy, 65(12), 1506-1524. https://doi.org/10.1111/j.1398-9995.2010.02449.x

Schmitt, J., Spuls, P. I., Thomas, K. S., Simpson, E., Furue, M., Deckert, S., \& Williams, H. C. (2014). The Harmonising Outcome Measures for Eczema (HOME) statement to assess clinical signs of atopic eczema in trials. Journal of Allergy and Clinical Immunology, 134(4), 800-807. https://doi.org/10.1016/j.jaci.2014.07.043

Schmitt, J., Buske-Kirschbaum, A., Tesch, F., Trikojat, K., Stephan, V., Abraham, S., \& Roessner, V. (2017). Increased attention-deficit/hyperactivity symptoms in atopic dermatitis are associated with history of antihistamine use. Allergy, 73(3), 615-626. https://doi.org/10.1111/all.13326

Silverberg, J. I. (2017). Selected comorbidities of atopic dermatitis: Atopy, neuropsychiatric, and musculoskeletal disorders. Clinics in Dermatology, 35(4), 360-366. https://doi.org/10.1016/j.clindermatol.2017.03.008

Silverberg, J. I. (2019). Comorbidities and the impact of atopic dermatitis. Annals of Allergy, Asthma \& Immunology, 123(2), 144-151. https://doi.org/10.1016/j.anai.2019.04.020

Simpson, E. L. (2012). Comorbidity in atopic dermatitis. Current dermatology reports, 1(1), 29-38. https://doi.org/10.1007/s13671-011-0003-5

Simpson, E. L., Villarreal, M., Jepson, B., Rafaels, N., David, G., Hanifin, J., \& Beck, L. A. (2018). Patients with atopic dermatitis colonized with staphylococcus aureus have a distinct phenotype and endotype. Journal of Investigative Dermatology, 138(10), 22242233. https://doi.org/10.1016/j.jid.2018.03.1517

Strom, M. A., Fishbein, A. B., Paller, A. S., \& Silverberg, J. I. (2016). Association between atopic dermatitis and attention deficit hyperactivity disorder in U.S. children and adults. British Journal of Dermatology, 175(5), 920-929. https://doi.org/10.1111/bjd.14697

Theiner, P. (2012). ADHD od dětství do dospělosti. Psychiatrie pro praxi, 13(4), 148-150.

Tsai, J., Chang, S., Mou, C., Sung, F., \& Lue, K. (2013). Association between atopic diseases and attention-deficit/hyperactivity disorder in childhood: A population-based case-control study. Annals of Epidemiology, 23(4), 185-188. https://doi.org/10.1016/j.annepidem.2012.12.015 
Tsakok, T., Woolf, R., Smith, C.H., Weidinger, S., \& Flohr, C. (2019). Atopic dermatitis: The skin barrier and beyond. British Journal of Dermatology, 180(3), 464-474. https://doi.org/10.1111/bjd.16934

Vachiramon, V., Tey, H., Thompson, A. E., \& Yosipovitch, G. (2012). Atopic dermatitis in African American children: Addressing unmet needs of a common disease. Pediatric Dermatology, 29(4), 395-402. https://doi.org/10.1111/j.1525-1470.2012.01740.x

van der Schans, J., Cicek, R., de Vries. T.W. et al. (2017). Association of atopic diseases and attention-deficit/hyperactivity disorder: A systematic review and meta-analyses. Neuroscience and Biobehavioral Reviews, 74, 139-148. https://doi.org/10.1016/j.neubiorev.2017.01.011

Weidinger, S., Beck, L. A., Bieber, T., Kabashima, K., \& Irvine, A. D. (2018). Atopic dermatitis. Nature Reviews Disease Primers, 4(1). https://doi.org/10.1038/s41572-0180001-Z

Yaghmaie, P., Koudelka, C. W., \& Simpson, E. L. (2013). Mental health comorbidity in patients with atopic dermatitis. Journal of Allergy and Clinical Immunology, 131(2), 428433. https://doi.org/10.1016/j.jaci.2012.10.041

\section{Údaje o autorech}

Doc. PhDr. Alena Hricová, Ph.D. přednáší na Zdravotně sociální fakultě JU a na Pražské vysoké škole psychosociálních studií.

\section{Kontaktní údaje:}

Adresa: Jihočeská univerzita v Českých Budějovicích, Zdravotně sociální fakulta, Jírovcova 24, České Budějovice

E-mail: ali.kajanova@email.cz

Mgr. Stanislav Ondrášek, Ph.D. je odborným asistentem na Ústavu sociálních a speciálněpedagogických věd Zdravotně sociální fakulty JU.

Email: ondrasek@zsf.jcu.cz

Bc. Matyáš Hric, podnikatel, nepůsobí v akademické sfeěre.

E-mail: hric@magnetrip.cz

Hricová, A., Ondrášek, S., \& Hric, M. (2021). Vztah atopického ekzému a pozornosti. E-psychologie, 15(3), 16-26. https://doi.org/10.29364/epsy.411 